Jurnal Media Agribisnis Vol. 3 No. 1 Tahun 2018 Hal 39 - 47

Media Komunikasi Hasil Penelitian Bidang Ilmu Agribisnis

ISSN print 2587-7027

ISSN online 2541-6898

\title{
PENDAPATAN USAHATANI NANAS (Ananas Comosus L.) DI DESA TANGKIT BARU KECAMATAN SUNGAI GELAM KABUPATEN MUARO JAMBI
}

\author{
Asmaida $^{1)}$ dan Zarkasih $^{2)}$ \\ ${ }^{1)}$ Program Studi Agribisnis, Fakultas Pertanian Universitas Batanghari \\ ${ }^{2}$ Alumni Program Studi Agribisnis, Fakultas Pertanian Universitas Batanghari \\ Jl. Slamet Riyadi, Broni Jambi. 36122. Telp. +6274160103 \\ *email korespondensi: asmaida.syandri@yahoo.co.id
}

\begin{abstract}
This research was conducted in Tangkit Baru Village, Sungai Gelam Sub-District, Muaro Jambi Regency. The location was selected purposively based on that this village has produced the highest pinapple among the villages in the sub district. The research took place since june 2017.

This research aims was to find out the description of the business activities of pineapple farming, production costs and income obtained by farmers from the pineapple farming business in Tangkit Baru Village, Sungai Gelam Sub-District, Muaro Jambi Regency. The number of samples taken in this research were 101 farmers which taken by simple random sampling method. To know the description of pineapple farming activity in the research area was analized by descriptive analysis.

The results of this research concluded that the income of pineapple farming was quite high with the average farmer income of Rp. 26,866,616,-/Ha/Year. Beside average, total cost was Rp. 2.646.184,-/Ha/Year, while the total revenue was Rp. 29.512.800,/Ha/Year.
\end{abstract}

Keywords: Income, Pinapple, Production

\begin{abstract}
Abstrak
Penelitian ini dilakukan di Desa Tangkit Baru, Kecamatan Sungai Gelam, Kabupaten Muaro Jambi. Lokasi dipilih secara purposif berdasarkan desa ini menghasilkan nanas tertinggi di antara desa-desa di kecamatan Sungai Gelam. Penelitian ini berlangsung sejak Juni 2017.

Penelitian ini bertujuan untuk mengetahui gambaran kegiatan usaha budidaya nanas, biaya produksi dan pendapatan yang diperoleh petani dari usaha budidaya nanas (Ananas comosus L.) di Desa Tangkit Baru, Kecamatan Sungai Gelam, Kabupaten Muaro Jambi. Jumlah sampel yang diambil dalam penelitian ini adalah 101 rumah tangga petani (RTP) yang dipilih secara acak (simple random sampling). Untuk mengetahui gambaran aktivitas budidaya nanas di Desa Tangkit Baru dianalisis secara deskriptif. Dari hasil penelitian ini dapat disimpulkan bahwa pendapatan usahatani nanas di Desa Tangkit Baru cukup besar dengan rata-rata pendapatan petani
\end{abstract}


Jurnal Media Agribisnis Vol. 3 No. 1 Tahun 2018 Hal 39 - 47

Media Komunikasi Hasil Penelitian Bidang Ilmu Agribisnis

ISSN print 2587-7027

ISSN online 2541-6898

sebesar Rp. 26.866.616 per hektar per tahun. Selain pendapatan, biaya total yaitu Rp. 2.646.184,-/Ha/Tahun, sedangkan total penerimaan Rp. 29.512.800,-/Ha/Tahun.

Kata kunci: Pendapatan, nanas, produksi

\section{PENDAHULUAN}

Sektor pertanian memiliki peran penting terhadap perekonomian nasional dari sisi pembangunan ekonomi nasional. Hal ini dapat dilihat dari kontribusi terhadap produk domestik bruto, penyerap tenaga kerja. neraca perdagangan. penyedia bahan pangan. bahan energi, pakan dan bahan baku industri, serta sumber pendapatan masyarakat di pedesaan.

Salah satu produk unggulan tanaman holtikultura khususnya tanaman buah yakni nanas. Nanas (Ananas comosus L.) adalah salah satu komoditas buah unggulan di Indonesia. Hal ini mengacu pada besarnya produksi nanas yang menempati posisi ketiga setelah pisang dan mangga. Selain dikonsumsi dalam bentuk segar, buah nanas juga dapat diolah menjadi berbagai produk seperti jus, selai, sirup dan keripik. Buah nanas mengandung unsur air, gula, asam organik, mineral, nitrogen, protein, bromelin serta semua vitamin dalam jumlah kecil, kecuali vitamin D. Kulit buah nanas dapat diolah menjadi sirup atau diekstraksi cairannya untuk pakan ternak, sedangkan serat pada daun dapat diolah menjadi kertas dan tekstil (Hadiati dan Indriyani. 2008).

Produksi nanas Indonesia cukup besar, berdasarkan Angka Tetap (ATAP) tahun 2014 produksi nanas mencapai 1.84 juta ton. Untuk wilayah Asia Tenggara, Indonesia termasuk penghasil nanas terbesar ketiga setelah Filipina dan Thailand dengan kontribusi sekitar 23\%. Hampir seluruh wilayah Indonesia merupakan daerah penghasil nanas karena didukung oleh iklim tropis yang sesuai. Namun demikian pengembangan nanas belum mendapat perhatian serius karena belum berkembangnya penggunaan varietas unggul dan belum optimalnya teknik budidaya (Hadiati dan Indriyani, 2008).

Produksi tertinggi buah nanas di Kecamatan Sungai Gelam terdapat di Desa Tangkit Baru yaitu sebesar 10.101 ton/tahun dan produktivitasnya sebesar 162.92 ton/Ha, dan produktivitas nanas ini masih berada di bawah produktivitas Kecamatan Sungai Gelam yakni sebesar 178,14 ton/Ha . Akan tetapi produktivitas ini masih dapat ditingkatkan mengingat potensi yang besar untuk pengembangan komoditi nanas di Desa Tangkit baru ini serta sebagian besar masyarakatnya adalah sebagai petani nanas.

Kegiatan penanaman komoditas pertanian, termasuk nanas pada lahan yang dikuasai atau dimiliki petani, selain untuk mencukupi keperluan sendiri, selalu diikuti dengan harapan dapat diperoleh tambahan pendapatan. Untuk itu, informasi nilai tambah atau keuntungan hasil usahatani merupakan salah satu pendekatan yang sangat tepat. Namun harus disadari bahwa nilai tambah yang diperoleh akan sangat beragam tergantung lokasi, kondisi iklim, jenis tanah, waktu tanam, kesuburan tanah, 
Jurnal Media Agribisnis Vol. 3 No. 1 Tahun 2018 Hal 39 - 47

Media Komunikasi Hasil Penelitian Bidang Ilmu Agribisnis

ISSN print 2587-7027

ISSN online 2541-6898

pemeliharaan tanaman, keterampilan petani, ketersediaan saprodi, dan faktor-faktor penunjang lain.

Berdasarkan hal tersebut, seingga penulis tertarik untuk mengetahui gambaran kegiatan usahatani Nanas (Ananas Comosus L.), biaya produksi pada usahatani nanas dan pendapatan usahatani nanas di Desa Tangkit Baru Kecamatan Sungai Gelam Kabupaten Muaro Jambi.

\section{METODOLOGI PENELITIAN}

Penelitian dilaksanakan pada bulan Juni tahun 2017 di Desa Tangkit Baru Kecamatan Sungai Gelam Kabupaten Muaro Jambi, yang merupakan sebagai salah satu desa setra produksi nanas dan jumlah produksinya tertinggi di Kecamatan Sungai Gelam.

Metode yang dipergunakan dalam penelitian ini adalah metode survei. Jenis data yang digunakan adalah data Cross section dengan skala ukur rasio. Data dalam penelitian ini bersumber dari data primer dan sekunder. Data primer diperoleh dari petani sampel melalui wawancara dengan menggunakan daftar kuisioner yang telah disusun sesuai dengan tujuan penelitian dan berdasarkan observasi atau pengamatan dilapangan. Sedangkan data sekunder diperoleh dari dinas atau instansi-instansi terkait yang berhubungan dengan penelitian.

Berdasarkan data BPS Kabupaten Muaro Jambi tahun 2016 Kecamatan Sungai Gelam Kabupaten Muaro Jambi, Desa Tangkit Baru memiliki total populasi petani nanas berjumlah 675 Rumah Tangga Petani (RTP). Menurut Winarno (1994) bila populasi cukup homogen, terhadap populasi dibawah 100 dapat digunakan sampel sebanyak 50\%, bila populasi di atas 100 dapat diambil sebesar $15 \%$ dan juga sampel manusia hendaknya diatas 30 orang besarnya. Berdasarkan Pendapat Winarno tersebut, maka peneliti mengambil sampel sebanyak 15\% (101 RTP) dari total 675 RTP.

Data yang diperoleh dari penelitian dilapangan ditabulasi kemudian dianalisis secara deskriptif kualitatif-kuantitatif dan interperensi untuk untuk menjawab perumusan masalah tentang gambaran usaha tani Nanas (Ananas Comosus L.), biaya produksi pada usaha tani nanas dan pendapatan usaha tani nanas di Desa Tangkit Baru Kecamatan Sungai Gelam Kabupaten Muaro Jambi. Dalam Soekartawi (2003), untuk menghitung total biaya produksi dalam usahatani adalah menggunakan rumus :

Dimana :

$$
\mathrm{TC}=\mathrm{FC}+\mathrm{VC}
$$

$\mathrm{TC}=$ Total Cost atau Total biaya $(\mathrm{Rp} / \mathrm{Ha} / \mathrm{Thn})$

$\mathrm{FC}=$ Fixed cost atau biaya tetap $(\mathrm{Rp} / \mathrm{Ha} / \mathrm{Thn})$

$\mathrm{VC}=$ Variabel cost atau biaya veriabel $(\mathrm{Rp} / \mathrm{Ha} / \mathrm{Thn})$

Untuk menghitung besarnya biaya tetap, dihitung berdasarkan nilai penyusutan alat yang digunakan, menggunakan rumus sebagai berikut (Syafri,2002). 
Jurnal Media Agribisnis Vol. 3 No. 1 Tahun 2018 Hal 39 - 47

Media Komunikasi Hasil Penelitian Bidang Ilmu Agribisnis

ISSN print 2587-7027

ISSN online 2541-6898

$\mathrm{D}=\frac{\mathrm{C}-\mathrm{S}}{\mathrm{N}}$

Keterangan :

$\mathrm{D}=$ Biaya Penyusutan Alat $(\mathrm{Rp} / \mathrm{Ha} / \mathrm{Thn})$

$\mathrm{C}=$ Nilai Awal alat (Rp)

$\mathrm{S}=$ Nilai Akhir alat (Rp) asumsi sama dengan nol

$\mathrm{N}=$ Perkiraan Umur Ekonomis (Thn)

Pendapatan usahatani adalah penerimaan usahatani yang diperoleh dari perkalian antara produksi dengan harga jual. Untuk menghitung besarnya pendapatan yang diperoleh dapat digunakan rumus (Soekartawi, 2003), sebagai berikut :

Dimana $\pi=$ TR - TC

$\Pi=P h \imath$ alau penuapalan (кp/ $\mathrm{na} / \mathbf{1} \mathrm{nn})$

$\mathrm{TR}=$ Total Revenue atau Total Penerimaan $(\mathrm{Rp} / \mathrm{Ha} / \mathrm{Thn})$

$\mathrm{TC}=$ Total Cost atau Total Biaya ( $\mathrm{Rp} / \mathrm{Ha} / \mathrm{Thn})$

Sedangkan menghitung besarnya penerimaan yang diperoleh dapat digunakan rumus sebagai berikut menurut Samuelson dan Nordhaus (2003):

Kete $\mathrm{TR}=\mathrm{Pq} \cdot \mathrm{Q}$

$\mathrm{TR}=$ Total Revenue atau Total Penerimaan $(\mathrm{Rp} / \mathrm{Ha} / \mathrm{Thn})$

$\mathrm{Pq}=$ Harga Produk $(\mathrm{Rp} / \mathrm{Kg})$

$\mathrm{Q}=$ Jumlah Produksi $(\mathrm{Kg} / \mathrm{Ha} / \mathrm{Thn})$

\section{Identitas Petani Sampel}

\section{HASIL DAN PEMBAHASAN}

Identitas petani sampel adalah ciri-ciri yang dimiliki oleh petani dalam hubungannya dengan usaha sebagai petani nanas yang terdiri dari: (1) umur petani (2) tingkat pendidikan, (3) jumlah tanggungan keluarga, (4) pengalaman berusahatani (5) penggunaan lahan.

Umur petani yang melaksanakan kegiatan usahatani nanas di Desa Tangkit Baru berkisar dari umur 25 - 65 tahun dengan rata-rata umur responden berkisar 44 tahun. Umur petani masih tergolong dalam usia produktif. Hal ini senada dengan pendapat Suharto dalam Asmaida (2017), usia kerja produktif berkisar antara 14 - 55 tahun, yang pada tingkat umur ini diharapkan seseorang sudah dapat bekerja dan menghasilkan pendapatannya sendiri. Umur dapat mempengaruhi kemampuan seseorang untuk bekerja dan mengelola usahataninya, baik itu pada proses produksi ataupun pengolahan lahan pertanian. Semakin tinggi umur petani kemampuan fisik petani untuk bekerja pada lahan usahataninya relatif menurun, karena pada umumnya petani hanya mengandalkan kekuatan fisik atau tenaga saja dalam melakukan kegiatannya. 
Jurnal Media Agribisnis Vol. 3 No. 1 Tahun 2018 Hal 39 - 47

Media Komunikasi Hasil Penelitian Bidang Ilmu Agribisnis

ISSN print 2587-7027

ISSN online 2541-6898

Pendidikan adalah hal yang sangat penting dalam kehidupan sebagai dasar memperoleh pengetahan dan keterampilan. Tingkat pendidikan petani sampel di Desa Tangkit Baru mulai dari yang tidak bersekolah sampai dengan SLTA/Sederajat. Sebagian besar tingkat pendidikan petani sampel hanya $\mathrm{SD} /$ Sederajat, yaitu sebesar 47,52\%. Maka secara keseluruhan tingkat pendidikan petani sampel masih tergolong rendah. Rendahnya tingkat pendidikan petani akan berpengaruh terhadap perencanaan dalam pengelolaan usahataninya, hal ini akan mempengaruhi tingkat produksi yang dihasilkan petani tersebut. Asmaida (2017), menyatakan bahwa semakin tinggi tingkat pendidikan petani maka kemampuan petani untuk meningkatkan pengelolaan usahataninya akan lebih baik terutama dari segi teknologi baru, pemahaman bercocok tanam.

Jumlah tanggungan keluarga merupakan salah satu faktor yang mempengaruhi keberhasilan berusahatani, semakin banyak jumlah tanggungan keluarga maka semakin banyak kebutuhan yang akan dipenuhi oleh petani. Rata-rata jumlah tanggungan keluarga petani sampel adalah sebanyak 3 orang. Asmaida (2017), menyatakan jumlah anggota yang menjadi tanggungan keluarga merupakan salah satu faktor yang mempengaruhi keberhasilan usahatani padi, anggota keluarga secara fungsional dapat dimanfaatkan sebagai modal sumberdaya/tenaga kerja dalam usahatani, sekaligusjuga sebagai beban tanggungan keluarga yang nantinya akan berpengaruh terhadap ekonomi keluarga petani tersebut. Pengalaman berusahatani yang dimaksud adalah lamanya petani sampel berusahatani, yang dinyatakan dalam tahun. Menurut Hernanto (1989), pengalaman berusahatani berperan terhadap penyesuaian usahatani agar sejalan dengan kemajuan dan perkembangan teknologi berusahatani. Pengalaman berusahatani petani sampel dalam berusahatani berkisar antara $10-49$ tahun, sebagian besar petani berpengalaman $20-24$ tahun yaitu sebanyak 21 RTP atau sebesar 20,79\%. Rata-rata pengalaman petani adalah 25,6 tahun. Dari data diatas, maka dapat dikatakan petani sampel di Desa Tangkit Baru sudah mempunyai pengalaman yang cukup lama dalam pengelolaan usahatani nanas, sehingga dapat bermanfaat untuk meningkatkan produksi dan mengembangkan usahatani nanas dimasa yang akan datang.

Lama pengalaman responden dalam berusahatani padi di Desa Tangkit Baru berkisar antara 5-40 tahun, dengan rata-rata pengalaman 32 tahun. Asmaida (2017), menyatakan bahwa responden memiliki pengalaman yang cukup lama dalam berusahatani dengan demikian diharapkan petani dapat melakukan usahataninya dengan baik dan lebih terampil dalam mengambil keputusan dalam pengelolaan usahatani padi sehingga mampu meningkatkan produksi usahatani padi yang pada akhirnya dapat meningkatkan pendapatan.

Luas lahan adalah berapa banyak lahan yang digarap oleh patani nanas dalam kegiatan usahataninya. Luas lahan merupakan variabel yang berperan penting dalam produksi nanas, semakin banyak jumlah luas lahan yang dimiliki oleh petani maka semakin besar peluang untuk memperoleh produksi yang relatif besar. Di Desa 
Jurnal Media Agribisnis Vol. 3 No. 1 Tahun 2018 Hal 39 - 47

Media Komunikasi Hasil Penelitian Bidang Ilmu Agribisnis

ISSN print 2587-7027

ISSN online 2541-6898

Tangkit Baru luas lahan yang dimiliki petani bervariasi, mulai dari luas lahan 1 hektar sampai dengan 4 hektar. Rata-rata luas lahan petani sampel di Desa Tangkit Baru adalah seluas 2,5 hektar.

\section{Gambaran Kegiatan Usahatani Nanas di Desa Tangkit Baru}

Tanaman nanas merupakan tanaman yang telah lama dibudidayakan di Desa Tangkit Baru Kecamatan Sungai Gelam Kabupaten Muaro Jambi dan merupakan salah satu usaha turun temurun. Saat ini usahatani nanas menjadi sumber mata pencaharian utama bagi masyarakat di Desa Tangkit Baru. Petani nanas mengelompokkan tanaman nanas dalam satu kebun dengan cara penanaman monokultur. Hal ini dikarenakan tanaman nanas memerlukan perawatan yang intensif dimana setiap hari petani harus mengontrol tanaman tersebut. Tanaman nanas mulai dapat menghasilkan setelah tanaman berumur 12 bulan, setiap kali pemanenan hasil yang diproduksi sekitar 60 - 80 persen. Tanaman yang sudah berumur lebih dari empat tahun diremajakan kembali. Nanas yang dibudidayakan di desa ini adalah Nanas Varietas Tangkit, yang sudah ditetapkan sebagai komoditi unggulan dari Provinsi Jambi melalui SK Menteri Pertanian No. 103/kpts/TP.2004/3/2000 pada tahun 2000 dan termasuk dalam golongan nanas queen, bibit yang ditanam adalah bantuan dari Dinas Pertanian dan petani tidak mengeluarkan biaya untuk bibit. Pada budidaya tanaman nanas jarak tanam sangat berpengaruh terhadap hasil dan ukuran buah. Di Desa Tangkit Baru petani rata-rata menggunakan sistem rangkap 3 dengan jarak tanam 50 x $50 \mathrm{~cm}$ dan jarak antar baris $100 \mathrm{~cm}$, jadi dalam satu meter persegi ditanami 9 rumpun nanas.

Pemupukan dilakukan setelah tanaman berumur 3 bulan dengan menggunakan pupuk Urea dan KCL dengan pebandingan 2 : 1. Pemupukan selanjutnya dilakukan selama 4 bulan sekali atau 3 kali per tahun. Pemberian obat-obatan seperti herbisida perlu dilakukan untuk membersihkan gulma disekitar tanaman nanas. Herbisida yang biasa digunakan adalah jenis Bimaron. Penyemprotan herbisida ini dilakukan 2 kali per masa tanam dengan rata-rata penggunaan obat-obatan 1,5 L/Ha atau $3 \mathrm{~L} / \mathrm{Ha} / \mathrm{Thn}$.

Tenaga kerja pada usahatani nanas di Desa Tangkit Baru rata-rata menggunakan tenaga kerja dari dalam keluarga dan tidak mengeluarkan biaya atau upah tenaga kerja. Hal ini untuk meminimalisirkan biaya yang dikeluarkan pada usahatani nanas, sehingga petani sampel harus bekerja setiap hari di lahan usahataninya.

Produksi nanas yang dihasilkan dari kegiatan usahatani nanas di Desa Tangkit Baru rata-rata 81.368 buah per tahun atau 32.792 buah per hektar per tahun dengan harga jual rata-rata Rp. 900,- per buah

\section{Biaya Produksi Usahatani Nanas}

Biaya produksi adalah total biaya yang digunakan dalam proses produksi yang terdiri dari biaya tetap dan biaya tidak tetap. Biaya tetap adalah biaya yang 
Jurnal Media Agribisnis Vol. 3 No. 1 Tahun 2018 Hal 39 - 47

Media Komunikasi Hasil Penelitian Bidang Ilmu Agribisnis

ISSN print 2587-7027

ISSN online 2541-6898

dikeluarkan dalam proses produksi yang tidak habis dalam satu kali produksi. Biaya tidak tetap adalah biaya yang digunakan dalam proses produksi dan habis dipakai dalam satu kali proses produksi.

Biaya produksi untuk usahatani nanas di Desa Tangkit Baru yang terbesar adalah komponen biaya tidak tetap yaitu sebanyak Rp. 2.580.000,- per hektar per tahun atau sebesar $97,50 \%$ yang terdiri dari biaya pembelian pupuk Urea, KCL dan Herbisida. Sedangkan untuk biaya tetap hanya sebanyak Rp. 66.184,- per hektar per tahun atau sebesar $2,50 \%$.

\section{Penerimaan dan Pendapatan Usahatani Nanas}

Penerimaan usahatani nanas adalah nilai uang yang diterima dari penjualan nanas yang merupakan perkalian antara jumlah produksi dengan harga jual nanas sedangkan Pendapatan usahatani nanas adalah selisih antara penerimaan dan total biaya produksi uahatani nanas.

Rata-rata produksi nanas yang diperoleh selama satu tahun di Desa Tangkit Baru adalah sebesar $32.792 \mathrm{Buah} / \mathrm{Ha} / \mathrm{Thn}$ dengan harga jual Rp. 900,-/buah, sehingga rata-rata penerimaan usahatani nanas petani sampel di Desa Tangkit Baru adalah sebesar Rp. 29.512.800,- per hektar per tahun.

Rata-rata pendapatan usahatani nanas petani di Desa Tangkit Baru adalah sebesar Rp. 26.866.616,-per hektar per tahun. Jika dilihat dari tingkat kesejahteraan, petani di Desa Tangkit Baru belum tergolong sejahtera, karena nilai pendapatan petani nanas di Desa Tangkit Baru yaitu sebesar Rp. 1.865.737,22 per kapita per bulan masih berada di bawah upah minimum kerja Kabupaten Muaro Jambi yaitu sebesar Rp. 2.063.000,- per kapita per bulan (BPS Muaro Jambi 2016). 
Jurnal Media Agribisnis Vol. 3 No. 1 Tahun 2018 Hal 39 - 47

Media Komunikasi Hasil Penelitian Bidang Ilmu Agribisnis

ISSN print 2587-7027

ISSN online 2541-6898

\section{KESIMPULAN}

Berdasarkan hasil penelitian dan pembahasan dapat ditarik kesimpulan sebagai berikut:

1. Usahatani nanas di Desa Tangkit Baru Kecamatan Sungai Gelam Kabupaten Muaro Jambi merupakan salah satu usaha turun temurun. Tanaman mulai menghasilkan setelah berumur 12 bulan bulan setelah tanam. Varietas nanas yang ditanam tergolong jenis varietas nanas tangkit (Queen). Rata-rata petani di Desa Tangkit Baru menggunakan sistem tanam rangkap 3 dengan jarak 50 x 50 dengan jarak antar barisan $100 \mathrm{~cm}$. Pemupukan tanaman dilakukan 4 bulan sekali dengan rata-rata jumlah pupuk urea sebanyak $100 \mathrm{Kg} / \mathrm{Ha}$ dan $\mathrm{KCL} 50 \mathrm{Kg} / \mathrm{Ha}$, sedangkan penyemprotan herbisida dilakukan 2 kali per tahun dengan rata-rata 1,5 L/Ha. Rata-rata produksi nanas adaah 32.792 buah/ha/Thn dengan harga rata-rata $\mathrm{Rp}$. 900,- per buah.

2. Rata-rata biaya produksi usahatani nanas sebesar Rp. 2.646.184,-- per hektar per tahun yang terdiri biaya tetap hanya sebanyak Rp. 66.184,- per hektar per tahun dan biaya tidak tetap sebanyak Rp. 2.580.000,- per hektar per tahun.

3. Rata-rata pendapatan usahatani nanas petani sampel di Desa Tangkit Baru adalah sebesar Rp. 26.866.616,- per hektar per tahun.

\section{DAFTAR PUSTAKA}

Asmaida, 2017. Efisiensi Alokatif Faktor-Faktor Produksi Dan Pendapatan Usahatani Padi (Oryza Sativa L.) (Studi Kasus Di Desa Simpang Datuk Kecamatan Nipah Panjang Kabupaten Tanjung Jabungtimur). Jurnal Media Agribisnis Vol.2 No 2 Universitas Batanghari Jambi.

BPS Kabupaten Muaro Jambi. 2016. Kabupaten Muaro Jambi dalam Angka 2016.

Badan Pusat Statistik Muaro Jambi. Jambi.

BPS Kabupaten Muaro Jambi. 2016. Kecamatan Sungai Gelam dalam Angka 2016.

Badan Pusat Statistik Muaro Jambi. Jambi.

BPS Provinsi Jambi. 2016. Jambi dalam Angka 2016. Badan Pusat Statistik. Jakarta

Danil, M. 2002. Metode Penelitian Sosial Ekonomi. Bumi Aksara. Jakarta.

Dinas Pertanian Tanaman Pangan dan Hortikultura Tahun 2014. Kondisi Nanas di Kabupaten Muaro Jambi Tahun 2011 - 2014. Bappeda Kabupaten Muaro Jambi. Muaro Jambi.

Dinas Pertanian Tanaman Pangan Jakarta. 2010. Data Perkembangan tanaman Pangan Kabupaten. Jakarta.

Hadiati, S. dan Indriyani, N.L.P. 2008. Petunjuk Teknis Budidaya Nanas. Balai Penelitian Tanaman Buah Tropika.

Kementerian Pertanian. 2015. Inovasi Hortikultura Pengungkit Peningkatan Pendapatan Rakyat. Badan Penelitian dan Pengembangan Pertanian. Kementerian Pertanian. Jakarta. 
Jurnal Media Agribisnis Vol. 3 No. 1 Tahun 2018 Hal 39 - 47

Media Komunikasi Hasil Penelitian Bidang Ilmu Agribisnis

ISSN print 2587-7027

ISSN online 2541-6898

Maarende. 2008. Analisis Pendapatan Usahatani Nanas Di Desa Lobong Kecamatan Passi Kabupaten Bolaang Mongondow. Jurusan Sosial Ekonomi, Fakultas Pertanian Universitas Sam Ratulangi. Manado.

Nurdin H.S. 2010. Analisis Penerimaan Bersih Usaha Tanaman Pada Petani Nanas Di Desa Palaran Samarinda. JURNAL EKSIS 6 (1) 1267 - 1266.

Samuelson, P.A and Nordhaus, W.D. 2003. Ilmu Mikroekonomi Edisi 17. Terjemahan: Nur Rosyidah, Anna Elly, dan Bosco Carvallo. PT Media Global Edukasi. Jakarta.

Soeharjo dan Patong. 1973. Send-sendi Pokok Usahatani. Departemen Ilmu-ilmu Sosial Ekonomi. Fakultas Pertanian, Institut Pertanian Bogor. Bogor.

Soeharjo, D dan Patong. 1977. Sendi-sendi Pokok Ilmu Usahatani dan Penelitian Untuk Pengembangan Petani Kecil. UI Press. Jakarta.

Soekartawi, 2003. Analisis Usahatani. Penerbit Universitas Indonesia (UI-Press). Jakarta.

Syafri.2002. Akuntasi Aktiva tetap. Bumi Aksara. Jakarta.

Winarno. S. 1994. Pengantar Penelitian Ilmiah (dalam metode teknik). Kanasius. Bandung. 